\title{
Comparative Analyze on the Legal Solution Relevant to Status of Teachers in Albania
}

\author{
Andon Kume
}

\section{ABSTRACT}

Legislative reforms in the pre-university education system in Albania have paid special attention to addressing issues related to teacher status. In law no.69 / 2012, "On the pre-university education system in the Republic of Albania", these issues are treated in accordance with the requirements of International Labor Conventions, the Labor Code of the Republic of Albania and law No. 10171, dated 22.10. 2009 "On regulated professions in the Republic of Albania" amended. The law defines the teacher as the central figure of the school. In accordance with the recommendations of the ILO and UNESCO for the status of teachers, the Albanian law guarantees contemporary standards at every stage of the process for gaining and practicing the profession, for continuous professional preparation, scientific qualification, and career. The treatment of labor relations, relations with the social partners, with the associations and the community of parents and students, the definition of their rights and duties, salaries and rewards are components of the status of a teacher.

The status of teachers reflects the social and economic conditions of the country, work culture and community traditions. The law treats teacher status as a key factor in developing the profile of a teacher capable of preparing the future citizens of an open and global society. The professional and academic freedom of the teacher is considered as an essential element of his status. Creating conditions for the exercise of civil rights related to the teaching profession, the right to participate in social and public life and to organize in trade unions are legislative achievements in line with $\mathrm{EU}$ standards and the requirements of international documents.

Keywords: Legislation, teacher, statute, Albania.

\section{INTRODUCTION}

About 60 years ago, [11] emphasized that "Teachers are human enough to want and need appropriately high status in our society. They belong to a profession which historically counted the community`s high regards as a part of the compensation for the teacher's labor".

In our present society it is no wonder that so few outstanding young people seek teaching as a career. The problem is not solely an economic one. The profession of teaching has offered an opportunity to live worth-while lives in the service of mankind. In that sense, teaching has been a "calling" to which teachers have dedicated themselves [11].

The concepts of status and professionalism are key issues in teacher teaching and education [1]. Internationally, the status of teachers is fraught with uncertainty, contradiction, and complexity. Status, defined simply as "staying in society," has undergone many redefinitions as lives and societies have become more nuanced and complex. Status, historically described through inheritance and wealth, has been largely replaced by status achieved through the efforts, studies, and individual achievements [10]. In the present time
Published Online: July 15, 2021

ISSN: $2736-4534$

DOI :10.24018/ejedu.2021.2.3.121

Andon Kume

University "Aleksandër Moisiu" Durrës, Albania.

(e-mail: andon.kume@ ${ }^{\circledR m a i l . c o m) ~}$

*Corresponding Author

teachers, in many countries but not universally, are highly trained, well qualified, committed and trusted in their communities [10]. Their participation in trade union activities fuels the debate over whether teaching should be classified as a "profession". However, despite the strong recommendation of UNESCO in 1966 and the International Labor Organization that teaching should be recognized as a profession and given a high status, it remains at best a semiprofessional profession.

[9], [10] point out that there are two classical theories about teacher status. The theory developed by Karl Marx and the theory of Max Weber. According to them, Marx considers the socio-economic factors as the most important, while for Weber the cultural and social ties are the main factors responsible for the status of teachers, which go beyond economic factors. Twentieth-century theorists, such as Talcott Parsons in the United States, have linked status to educational achievement. Pierre Bourdieu links status to the social reproduction of "habitus" associated with social class in taste and consumption, and Anthony Giddens to individual lifestyle choices not necessarily related to status [10]. 
The 2030 Agenda for Sustainable Development, in its Goal 4, has recognized the importance of qualified teachers in achieving inclusive and equitable quality education and lifelong learning opportunities for all. Agenda provide a set of overarching aims for the future of teacher status, envisaging teachers not as adults in a child's world, but as orchestrators of national sustainable development [19].

According to the UNESCO / ILO the various factors influence teacher status, covering a variety of contexts, from the global to the national, to the school and other related to the individual teacher. [21] emphasizes that ILO and UNESCO Recommendations 1966 and 1997 set a number of international standards for a wide range of issues related to teachers' most important concerns and affecting their status. These issues include: (a) initial and continuing training, (b) recruitment, (c) advancement and promotion, (d) security of tenure, (e) disciplinary procedures, (f) part-time service, (g) professional freedom, (h) supervision and assessment, (i) responsibilities and rights, (j) participation in educational decision-making, (k) negotiation, (l) conditions for effective teaching and learning, and (m) social security.

Addressing and resolving problems related to teacher status is a complex challenge. Among the potential contributing factors that need to be considered may be: (i) professional standards and training; (ii) the creation of professional associations, (iii)improved and safe conditions of work; (iv) higher pay linked to performance; (v) professional autonomy and involvement in decision-making; and (vi) teachers themselves rating their status more highly. The ILO / UNESCO Recommendation concerning the Status of Teachers (1966) and the UNESCO Recommendation concerning the Status of Higher-Education Teaching Personnel (1997) are two international instruments which can and should be used to address and resolve status issues teachers, adapting these solutions with the international requirements and standards.

The change in the political system that took place in the early `90s in Albania, had as a consequence the beginning of a deep reform process in the education system. An important part of this process is the reform of the legislative framework.

The Albanian legislative body, having as its basic objective the creation of a supporting legal framework for the development of an education system in line with the requirements and standards of the EU and capable of responding to the conditions of the global society, during these 30 years has addressed and resolve important aspects of this legislation. Part of them are also issues related to teacher status.

The purpose of this study is the analysis of the current Albanian legislation that deals with issues of teacher status, confronting it with the requirements and standards provided for this status in international documents and EU countries.

\section{Albanian Legislation RELEVANT to TEACHER'S STATUS}

There is no special document or act in the Albanian legislation, where the status of the teacher is treated as the only issue, in all aspects and components. They are addressed in various legal acts.
Law no. 69, dated 21.6.2012 "On pre-university education in the Republic of Albania", as amended, is the most important act in which issues of teacher status are addressed. The law is drafted in accordance with the Constitution of Albania, article 57, paragraph 1 "Everyone has the right to education". The main aims of this law are: (i) to define the basic principles regarding the structure, activity, and management of pre-universitary education system; (ii) to guarantee the constitutional right to education. In this law are addressed some of the key aspects related to the profession and status of the teacher, such as: (a) training, qualification, and professional development, (b) the rights and duties of the teacher, (c) admission and dismissal, etc.

Law No. 10 171, dated 22.10.2009 "On regulated professions in the Republic of Albania" as amended, addresses issues related to the teaching profession, as a regulated profession, which are complementary to those addressed in the law on education pre-university for teacher status. Among these issues, it is of particular importance to determine the criteria for practicing the teaching profession. The criteria have been drafted in accordance with the requirements that this profession must meet, in the service of protecting the public interest. As such, they form the legislative basis that guarantees the respect of the principle of independence and the autonomy of teachers in the exercise of the profession. Protection and guarantee of standards in the practice of the teaching profession, determination of conditions and criteria for the practice of the profession; qualifications to be achieved; procedures to be followed to gain the right to practice the teaching profession as a regulated profession; the responsibilities of the teacher and of the authorities responsible for the exercise of this profession are arguments that are treated in the law "On regulated professions in the Republic of Albania". Together with the arguments addressed in the law on the pre-university education system, they form an important part of the legislative framework that trains issues of teacher status in Albania.

Law no. 88722002 "On Vocational Education and Training", as amended, is the main legal act that addresses the issues of development of the education and vocational training system in the Republic of Albania. This law serves as the main legislative mechanism for the adaptation of the vocational education service to the new economic and social conditions, that are the result of social, economic, and technological changes and the needs of the open labor market. The law deals specifically with issues related to the teaching profession, standards and professional performance of teachers, relations with communities, employment conditions, pay and career support, etc. Addressing issues related to teacher status in the system of vocational secondary education is made in accordance with the features that vocational secondary education system has. Unlike the law on pre-university secondary education, for the status of teachers in this law special attention has been paid to the problems related to the professional training of teachers. The law emphasizes the need for ongoing training of teachers, for the development of their capacities and practical skills, which should guarantee the development of the teaching process and the transmission to students of theoretical 
knowledge and the formation of practical performance, necessary for the profession exercise.

Aspects and issues of teacher status are also addressed in Law no. 7961 of 12.07.1995 "Labor Code of the Republic of Albania", as amended. This is the basic legislative act that regulates employment issues in Albania, which should also apply to the teaching profession.

Based on and in implementation of the laws listed above, in Albania has been drafted a sub-legal framework, decisions of the Council of Ministers, instructions, orders and regulations of line ministries, which has as its main objective the development of institutional capacities and the drafting of policies for the status and evaluation of teachers in Albania. Among these acts can be listed:

Normative Provisions for the Pre-University Education System approved by the Ministry of Education and Science in 2020 [16]. This document elaborates in detail the rules for the learning process, conditions, requirements, rights and duties for teachers, its interaction and cooperation with the community of parents and students, rules for employment and working hours, salaries and teacher reward, teacher social position, evaluation and career.

Integral part of teacher status are a set of rules and requirements related to the Code of Ethics for teachers in public and private pre-university education. For the Code of Ethics of teachers, the legislation provides a model of behavior which makes possible the realization of the social mission that schools have in a democratic society. The purpose of the Code of Ethics is to help the teacher and other education staff, to recognize, understand and apply the ethical standards necessary for the realization of the mission of education and to make decisions in the framework of the realization of this mission. In Albanian legislation this Code is drafted in accordance with the principles on which the teaching profession should operate: (i) commitment to the student and to learning process and (ii) commitment to the profession.

Various aspects of teacher status are also addressed in bylaws, such as the instructions and orders of the Ministry of Education:

Instruction No.2, dated 05.02.2014 "On the criteria and procedures of teacher qualification", defines the qualification criteria for teachers, the qualification process, the tasks of various institutions for the progress of the qualification process, programs and qualification tests, its evaluation and certification.

Instruction No.56, dated 12.11.2013 "On the procedures of appointment and dismissal of teachers in the public institution of pre-university education", determine the procedures and documentation for hiring teachers, tasks and work of the evaluation commission, appointment procedure of the teacher by the principal, the dismissal of the teacher.

Instruction No.11. dated 17.05.2013 "On the functioning of the system of continuous professional development of educational staff", rules are set for the professional development of educational staff, including teachers.

Collective Labor Agreement, dated 25.05. 2010 is the basic document that regulates the employment relationship between teachers and their employers. Drafted in accordance with the requirements of Labor Code, this contract contains all the rights and duties for teachers, working conditions, duration of work, leave, salary, ethical rules and sanctions. The collective labor agreement is the basic document in which are treated the requirements of the legislation related to the teachers`status.

\section{COMPARATIVE ANALYSIS OF ALBANIAN LEGISLATION ON TEACHER STATUS AND REQUIREMENTS AND STANDARDS SET OUT IN INTERNATIONAL AND EU DOCUMENTS}

The ILO and UNESCO Recommendations 1966 and 1997 stipulate that teaching should be regarded as a profession: it is a form of public service which requires of teachers' expert knowledge and specialized skills, acquired, and maintained through rigorous and continuing study. In accordance with this recommendation, in the Albanian legislation the teaching profession is classified in the group of regulated professions [14]. It is treated as an obligation and public service [14]. Albanian legislation pays special attention to the problem of professional training of teachers [13] and their continuous qualification [15].

According to the UNESCO Recommendation concerning the Status of Higher-Education Teaching Personnel (1997) the teaching profession should enjoy academic freedom in the discharge of professional duties. In addition to this recommendation, the Albanian legislation recognizes the right of teachers to contribute to the preparation of teaching tools and for compilation the most appropriate methods for teaching. According to this legislation, the teacher, within the framework of approved programs, should have an essential role in the selection and adaptation of teaching material, in the selection of textbooks and the application of teaching methods [13], [ 16].

The professional standards relating to teacher performance are one important international standard related to the teacher status [1], [4], [5], [22]. These standards are addressed in detail in Albanian legislation. In law no. 69, dated 21.6.2012 "On pre-university education system in the Republic of Albania", article 57 stipulates that the teaching profession can be exercised only if the employee holds a university diploma in studies in the field of education. In this law, article 58 defines the obligation for continuous professional development of the teacher, which can be realized through trainings planned by educational institutions, participation in professional networks, counseling, short-term and / or longterm courses. Professional qualification is a necessary condition for career This qualification also conditions the increase of the teacher's salary (Article 59).

International standards recommend that the basic principles of the Code of Ethics for the teaching profession be part of national legislation. They should be created by teachers' organizations, as such codes contribute greatly to ensuring the prestige of the profession and the exercise of professional duties in accordance with the requirements of the collective labor contract. In the Albanian legislation the Code of Ethics is treated in [2].

Following the basic international principles, the Code of Ethics for Albanian teachers has been drafted in accordance with three basic principles: (i) commitment to the pupils on the basis of which the behaviors expected of the teacher in relation to the learning process are determined; (ii) commitment to the profession, on the basis of which the 
behaviors expected from the teacher are determined for the improvement of his personal qualities in function of learning and the educational environment that supports him in all directions and (iii) commitment to the community to create a more motivating environment for education.

The treatment and manner of resolving issues related to salary and working time have a particular importance for the status of teachers. In international documents [18] and experiences in other countries [6], [9], [17], [21]-[23] emphasize that both salaries and working conditions for teachers should be determined through a process of negotiation between teachers 'organizations and the employers of teachers. In the instruction no. 31, dated 20.01.2020 "On the regulation for the functioning of preuniversity education institutions in the Republic of Albania" are addressed, in detail, issues related to working hours and teachers' salary. The legislative solution to both of these issues is in line with the requirements of the Labor Code in the Republic of Albania [12]. The legal provisions for them, which are based on the main constitutional principles of labor law and remuneration, are also the main legal framework used by teachers' union organizations to draft the collective labor contract.

As recommended in international documents [19], in the Albanian legislation on teacher status are also addressed issues related to Individual rights and freedoms - civil rights, academic freedom, publication rights, and the international exchange of information, terms and conditions of employment of women, disabled and part-time teaching personnel.

\section{CONCLUSION}

The status of teachers in the Albanian pre-university system is part of the legislative reform of this system after the changes that occurred in the early ' 90 s in the political and economic system of Albania.

In the Albanian legislation there is not a single act in which the status of the teacher is treated in a complete and exhaustive way. The teacher's status consists of a set of provisions that are part of different laws and bylaws that address issues of the pre-university education system in Albania

The status of the Albanian teacher deals with issues related to the teaching profession and the requirements for its exercise, rights and duties as a regulated profession, the obligation for continuous qualification, salary and working time, career, relations with the employer, students and the community, code of ethics, participation in trade unions, the right to collective bargaining.

The status of Albanian teachers reflects the principles, requirements and standards set out in international documents and experiences of EU countries. for the teaching profession and its practice.

\section{REFERENCES}

[1] Clarke, L. (2016) Teacher Status and Professional Learning https://www.criticalpublishing.com/linda-clarke.

[2] Code of Teacher Ethics in Public and Private Pre-University Education (2016). https://www.portalishkollor.al/institucion/kodi-i-etikes-semesuesit-ne-arsimin-parauniversitar-publik-dhe-privat.

[3] Convention ILO C087 - Freedom of Association and Protection of the $\begin{array}{lll}\text { Right to } & \text { Organise, }\end{array}$ https:/www.ilo.org/dyn/normlex/en/f?p=normlexpub:12100:0::no::p 12100_ilo_code:c087.

[4] Delgado, P. (2019) The Status of the Teacher: a Global Analysis. https://observatory.tec.mx/edu-news/status-of-teachers-globalanalysis.

[5] Everton, T., Turner, P., Hargreaves, L. \& Pell, T. (2007). Public perceptions of the teaching profession. Research Papers in Education, 22 (3), 247-265. https://www.tandfonline.com/doi/abs/10.1080/02671520701497548.

[6] Halai, A. 92007) Teacher status. A symposium. Aga Khan University Institute for Educational Developemet, Karachi, Pakistan. http://ecommons.aku.edu/cgi/viewcontent.cgi?article=1006\&context =books.

[7] Hansen, A. (2009) Researching 'teachers in the news': the portrayal of teachers in the British national and regional press, Education 3-13: International Journal of Primary, Elementary and Early Years $\begin{array}{lll}\text { Education, } & 7: 4, & 335-347\end{array}$ https://www.tandfonline.com/doi/abs/10.1080/03004270903099900.

[8] Hargreaves L. \& Hopper, B. (2006) Early years, low status? Early years teachers' perceptions of their occupational status. Early Years, 26(2), $171-186$ https://www.tandfonline.com/doi/abs/10.1080/09575140600759971.

[9] Hargreaves, L. (2009) 'The status and prestige of teachers and teaching', (pp 217-230). In L. Saha \& G. Dworkin (Eds.) International Handbook of Research on Teachers and Teaching. New York, NY: Springer. e-ISBN 978-0-387-73317-3.

[10] Hargreaves, L., Flutter, J. (2019) The Status of Teachers. https://doi.org/10.1093/acrefore/9780190264093.013.288.

[11] Karl, O. B. (1962) Improving Teacher Status. Research Article. https://doi.org/10.1177/019263656204627206.

[12] Law no.7961 dated 12.7.1995 "For the Labor Code of the Republic of Albania". https://www.wipo.int/edocs/lexdocs/laws/en/al/al066en.pdf.

[13] Law No. 69, dated 21.6.2012 "On pre-university education in the Republic of Albania".

https://www.crca.al/en/law-pre-university-education-system-republicalbania.

[14] Law no.10171, dated 22.10.2009 "On regulated professions in the Republic of Albania". http://qsha.gov.al/infos/legjislacioni/ligj_10171.pdf.

[15] Law no 15/2017 "On Vocational Education and Training". https://financa.gov.al/wp-content/uploads/2018/06/ligj-nr-15-dt-16-22017.pdf.

[16] Order no.31, dated 28.01.2020 "Regulation on the functioning of preuniversity educational institutions in the Republic of Albania".

[17] Mutluer, Ö., Yüksel, S. (2019) The Social Status of the Teaching Profession: A Phenomenological Study. Journal of Teacher Education and Educators Volume 8, Number 2, p. 183-203. https://files.eric.ed.gov/fulltext/EJ1227825.pdf.

[18] Neelan, P. (2014) Teachers' knowledge of legislation and education law specifically and its influence on their practice. Dissertation (MEd)University of Pretoria. http://hdl.handle.net/2263/43224.

[19] The 2030 Agenda for Sustainable Development https://sdg4education2030.org/the-goal.

[20] The ILO/UNESCO (2016) Recommendation concerning the Status of Teachers (1966) and the UNESCO Recommendation concerning the Status of Higher-Education Teaching Personnel (1997) https://www.ilo.org/wcmsp5/groups/public/ed_dialogue/sector/docu ments/normativeinstrument/wcms_493315.pdf.

[21] Symeonidis, V. (2015) "The status of teachers and the teaching profession a study of education unions' perspectives." Education International Research Institute.Brussels, Belgium, www.ei-ie.org.

[22] Swann, M, McIntyre, D., Pell, T., Hargreaves, L. \& Cunningham, M (2010) 'Teachers' conceptions of teacher professionalism in England in 2003 and 2006', British Educational Research Journal, 36: 4, 549-571. https://files.eric.ed.gov/fulltext/EJ1159038.pdf.

[23] Warin, J., Maddock, M., Pell, A. \& Hargreaves, L. (2006) Resolving identity dissonance through reflective and reflexive practice in teaching, Reflective Practice, 7:2, 233-245 https://www.tandfonline.com/doi/abs/10.1080/14623940600688670. 


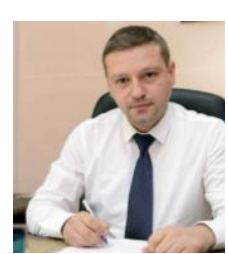

Andon Kume, Prof. Asoc. Dr.

Andon Kume completed high school in Florida, USA.

In 2010 he completed his university studies at the

University of Macerata, Faculty of Law, Italy.

In the period 2010-2013 he completed his doctoral

studies at The Department of Legal Sciences of the

University of Macerata, Italy. After finishing, with

excellent results, of Phd studies, he started working as the first lecturer at the University "Aleksandër Moisiu" Durrës ". In March 2015 he was awarded the academic title "Associate Professor".

His academic and teaching experience includes activating as a lecturer in several universities in the country and engaging as a scientific leader at the UET doctoral school.

He has participated, in a considerable number of symposia, international conferences and congresses and has published the results of his scientific research in domestic and foreign scientific journals. He is the author of three monographies.

From 2016 until today he has been elected Dean of the Faculty of Political and Legal Sciences at the "Aleksandër Moisiu" University, Durrës. 